\title{
Coordination of Rheb lysosomal membrane interactions with
}

\section{mTORC1 activation [version 1; peer review: 4 approved]}

\author{
Brittany Angarola1,2, Shawn M. Ferguson (iD1,2 \\ ${ }^{1}$ Department of Cell Biology, Yale University School of Medicine, New Haven, CT, 06510, USA \\ 2Department of Neuroscience, Program in Cellular Neuroscience, Neurodegeneration, and Repair, Yale University School of \\ Medicine, New Haven, CT, 06510, USA
}

\section{V1 First published: 27 May 2020, 9(F1000 Faculty Rev):450 \\ https://doi.org/10.12688/f1000research.22367.1 \\ Latest published: 27 May 2020, 9(F1000 Faculty Rev):450 \\ https://doi.org/10.12688/f1000research.22367.1}

\begin{abstract}
A complex molecular machinery converges on the surface of lysosomes to ensure that the growth-promoting signaling mediated by mechanistic target of rapamycin complex 1 (mTORC1) is tightly controlled by the availability of nutrients and growth factors. The final step in this activation process is dependent on Rheb, a small GTPase that binds to mTOR and allosterically activates its kinase activity. Here we review the mechanisms that determine the subcellular localization of Rheb (and the closely related RhebL1 protein) as well as the significance of these mechanisms for controlling mTORC1 activation. In particular, we explore how the relatively weak membrane interactions conferred by C-terminal farnesylation are critical for the ability of Rheb to activate mTORC1. In addition to supporting transient membrane interactions, Rheb C-terminal farnesylation also supports an interaction between Rheb and the $\delta$ subunit of phosphodiesterase 6 (PDES). This interaction provides a potential mechanism for targeting Rheb to membranes that contain Arl2, a small GTPase that triggers the release of prenylated proteins from PDES. The minimal membrane targeting conferred by C-terminal farnesylation of Rheb and RhebL1 distinguishes them from other members of the Ras superfamily that possess additional membrane interaction motifs that work with farnesylation for enrichment on the specific subcellular membranes where they engage key effectors. Finally, we highlight diversity in Rheb membrane targeting mechanisms as well as the potential for alternative mTORC1 activation mechanisms across species.
\end{abstract}

\section{Keywords}

lysosome, signaling, cancer, Rheb, mTOR, membranes

\section{Open Peer Review}

$\begin{array}{rrrr}\text { Approval Status } & \checkmark \\ 1 & 2 & 3 & 4\end{array}$

version 1

27 May 2020

Faculty Reviews are review articles written by the prestigious Members of Faculty Opinions. The articles are commissioned and peer reviewed before publication to ensure that the final, published version is comprehensive and accessible. The reviewers who approved the final version are listed with their names and affiliations.

1. Rolf Heumann, Ruhr-Universität Bochum, Bochum, Germany

2. David M Sabatini, Massachusetts Institute of Technology, The David H. Koch Institute for Integrative Cancer Research, Cambridge, USA Justin Roberts, Massachusetts Institute of Technology, The David H. Koch Institute for Integrative Cancer Research, Cambridge, USA

3. Robbie Loewith, University of Geneva, Sciences II, Geneva, Switzerland

4. Roberto Zoncu, University of California at Berkeley, Berkeley, USA 
Any comments on the article can be found at the end of the article.

Corresponding author: Shawn M. Ferguson (shawn.ferguson@yale.edu)

Author roles: Angarola B: Conceptualization, Writing - Original Draft Preparation, Writing - Review \& Editing; Ferguson SM:

Conceptualization, Funding Acquisition, Project Administration, Resources, Supervision, Writing - Original Draft Preparation, Writing Review \& Editing

Competing interests: No competing interests were disclosed.

Grant information: S.M.F was supported by a grant from the National Institutes of Health (GM105718).

The funders had no role in study design, data collection and analysis, decision to publish, or preparation of the manuscript.

Copyright: (c) 2020 Angarola B and Ferguson SM. This is an open access article distributed under the terms of the Creative Commons Attribution License, which permits unrestricted use, distribution, and reproduction in any medium, provided the original work is properly cited.

How to cite this article: Angarola B and Ferguson SM. Coordination of Rheb lysosomal membrane interactions with mTORC1 activation [version 1; peer review: 4 approved] F1000Research 2020, 9(F1000 Faculty Rev):450

https://doi.org/10.12688/f1000research.22367.1

First published: 27 May 2020, 9(F1000 Faculty Rev):450 https://doi.org/10.12688/f1000research.22367.1 


\section{Introduction}

The growth of cells is closely matched to changes in the availability of nutrients through a complex set of sensing and signaling mechanisms that regulate the kinase activity of the mechanistic target of rapamycin complex 1 (mTORC1). When nutrients are abundant, activation of mTORC1 results in the phosphorylation of numerous downstream targets to enhance anabolic processes such as nucleotide synthesis and protein translation and suppress catabolic processes such as autophagy and lysosome biogenesis. In many metazoan organisms, growth factor availability is also integrated into the activation of mTORC1 via regulation of the nucleotide-binding state of Ras homolog enriched in brain (Rheb), a small GTPase that binds to and allosterically activates the mTOR kinase when it is part of $\mathrm{mTORC} 1^{1,2}$.

mTOR is a large (289 $\mathrm{kDa})$ kinase that is a critical component of two complexes: mTORC1 and mTORC2. In this review, we focus on mTORC1, which contains mTOR as well as regulatory subunits including LST8 and Raptor that help with scaffolding, subcellular targeting, and substrate recognition ${ }^{3-7}$. Of note, Raptor plays a critical role in targeting mTORC1 to the surface of lysosomes via its interactions with the heterodimeric Rag GTPases ${ }^{8,9}$. The functionally distinct mTORC2 is made up of mTOR and LST8, along with a different set of interacting proteins, and does not require Rheb for its activation ${ }^{5,10,11}$

The cytoplasmic surface of lysosomes is the major site within cells where mTORC1 activation occurs ${ }^{8,9}$. mTORC1 activation is highly regulated and dependent on the convergence and integration of multiple signals relaying growth factor and nutrient availability to ensure that the cell growth-promoting activity of mTORC1 is matched to ongoing changes in environmental status $^{8,12-18}$. GTP-bound Rheb subsequently binds and activates mTORC1. This model requires mechanisms to regulate the abundance and nucleotide state of both Rag and Rheb GTPases on the surface of lysosomes. However, in contrast to the Rags, which are enriched on lysosomes via their interactions with the lysosome-localized Ragulator complex ${ }^{8,9,18,19}$, there has long been a mismatch between the widespread belief that Rheb abundantly resides on the surface of lysosomes and minimal direct evidence to support such a localization. This review highlights evidence that reconciles differences between Rheb steady-state localization and function via a model wherein transient interactions of Rheb with lysosomal membranes support mTORC1 activation (Figure 1).

\section{Rheb is a critical link between growth factor receptor signaling and $\mathrm{mTORC} 1$ activation}

Rheb was originally identified as a gene whose expression was upregulated by multiple stimuli that increased neuronal activity in the rat brain $^{20}$. Although it was discovered in this neuronal context, the broad expression pattern of Rheb suggested functions with relevance beyond the adaptive response of neurons to changes in activity ${ }^{20}$. Indeed, a major role for Rheb in the regulation of cell growth was subsequently revealed by genetic studies in Drosophila, which identified a critical

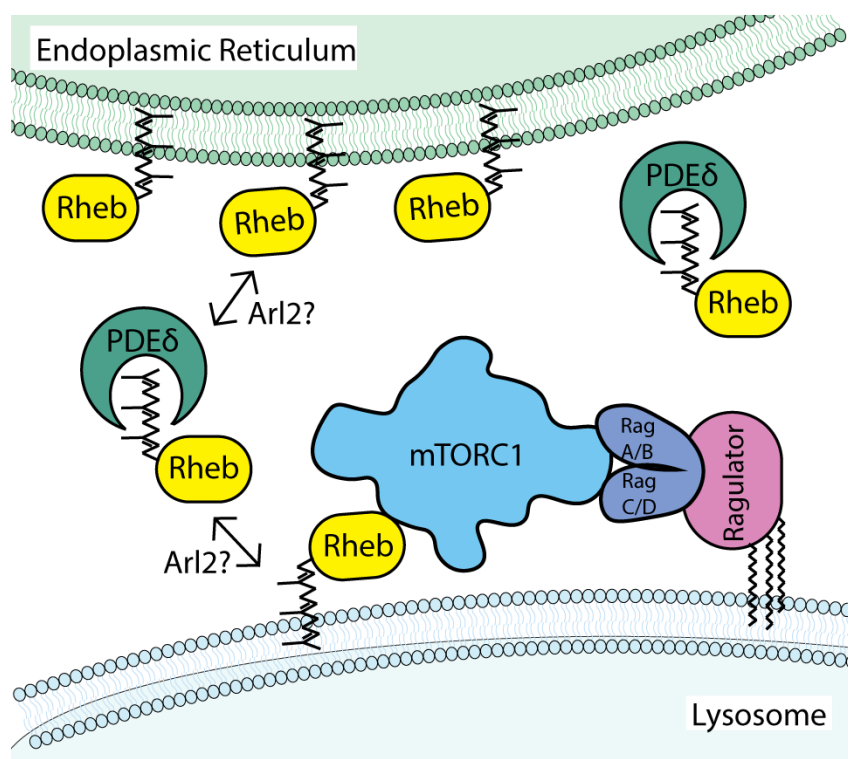

Figure 1. Dynamic interactions of Rheb with lysosomal membranes support the activation of mTORC1 signaling. In this model, farnesylation of Rheb is a major determinant of Rheb subcellular localization. The weak membrane association conferred by farnesylation means that steady-state levels of Rheb on lysosomes are low and influenced by additional factors such as sequestration in the cytoplasm by PDE $\delta$ and Arl2-dependent release on target membranes. In contrast to Rheb, the Rag GTPases are enriched on Iysosomal membranes through interactions with the pentameric Ragulator complex whose LAMTOR1/p18 subunit is both myristoylated and palmitoylated on an N-terminal glycine with two adjacent cysteines ${ }^{21}$. Although each of these cysteines represent putative sites of palmitoylation, it remains to be formally established whether they are simultaneously palmitoylated. Furthermore, it was recently reported that LAMTOR $1 / \mathrm{p} 18$ palmitoylation can be regulated in response to changes in amino acid availability ${ }^{22}$. Although simplified in this schematic diagram, mTORC1 is a dimer and can thus potentially engage a total of six GTPases on the surface of lysosomes (two Rag heterodimers that can be made up of different pairwise combinations of RagA or RagB with RagC or RagD plus two Rheb/RhebL1) ${ }^{1,23}$. mTORC1, mammalian target of rapamycin complex 1 ; PDE $\delta, \delta$ subunit of phosphodiesterase 6; Rheb, Ras homolog enriched in brain.

role for Rheb in promoting protein translation by activating mTORC1 signaling ${ }^{24-27}$. It was demonstrated that this function of Rheb is inhibited by the tuberous sclerosis complex (TSC), which acts as a GTPase-activating protein (GAP) for Rheb and thereby suppresses the ability of Rheb to activate mTORC1 by converting Rheb from the GTP- to GDP-bound state ${ }^{25,28-32}$. Growth factor signaling promotes Rheb-dependent activation of mTORC1 via AKT-dependent phosphorylation of the TSC2 subunit of TSC, which creates a 14-3-3 binding site on TSC2 and results in the sequestration of TSC2 away from lysosomes ${ }^{33-40}$. Loss-of-function mutations in the human TSC1 and TSC2 genes cause tuberous sclerosis, a disease characterized by mTORC1 hyperactivation and a variable constellation of distinct tumors as well as seizures and psychiatric disabilities ${ }^{41}$. Rheb has also been broadly implicated in a wide range of diseases 
including cancer, diabetes, aging, neurodegeneration, epilepsy, and autism, where excessive mTORC1 signaling plays a role ${ }^{18,42}$. The importance of mTORC1 over-activation in multiple disease states has motivated the development of pharmacological strategies for Rheb inhibition ${ }^{43}$.

Interestingly, given the abundant evidence demonstrating that regulating Rheb activity is critical in both health and disease, no guanine nucleotide exchange factor (GEF) has been identified for Rheb. Although translationally controlled tumor protein (TCTP) was proposed to act as a Rheb GEF, this conclusion was subsequently challenged ${ }^{44-46}$. The ubiquitin E3 ligase known as PAM was also proposed to be a Rheb GEF, but there have not been follow-up studies to substantiate that this is physiologically relevant ${ }^{47}$. In the absence of a GEF, it is thought that a relatively low nucleotide affinity allows Rheb to spontaneously exchange GDP for GTP ${ }^{45,46}$. The nucleotide state of Rheb is thus predicted to reflect the cellular GTP/GDP ratio when growth factor-dependent signaling has suppressed the GAP activity of TSC. As GTP generally predominates over GDP in cells, this results in a predominantly active state for $\mathrm{Rheb}^{29,30}$. In this active, GTP-bound state, Rheb can bind to mTORC1 and trigger long-range conformational changes that result in a reorganization and activation of the mTOR kinase domain ${ }^{1}$. Although this allosteric regulation of mTORC1 by Rheb is mediated by the GTP-bound state of Rheb, it appears that the affinity of the interaction between Rheb and mTORC1 is weak and/or transient such that the endogenous complex between Rheb and mTORC1 cannot readily be isolated from cells by conventional affinity purification methods ${ }^{30,48}$. Rheb thus differs from closely related small GTPases such as Ras proteins that bind to effectors such as Raf with high affinity ${ }^{49,50}$. Looking to the future, there is still a need to elucidate how mTOR conformational changes that are induced by Rheb are either maintained or terminated and how such steps contribute to the regulation of $\mathrm{mTORC} 1$ signaling.

\section{Rheb and RhebL1 function redundantly in the activation of $\mathrm{mTORC} 1$}

In addition to Rheb, whose role in mTORC1 activation is wellcharacterized, mammalian genomes also contain a gene for a related GTPase called Rheb-like 1 (RhebL1, also known as Rheb2) that shares only $\sim 52 \%$ amino acid identity with Rheb but is also able to activate mTORC1 when over-expressed ${ }^{51,52}$. Although their redundant ability to activate mTORC1 signaling has long been established by over-expression approaches, considerably less attention has been paid to physiological roles of RhebL1 and most studies have simply referred to Rheb as the activator of mTORC1. However, even though Rheb knockout (KO) mice have an embryonic lethal phenotype and exhibit defects in the activation of mTORC1, embryonic fibroblasts from these mice still grew in culture ${ }^{53-55}$. These cells maintained a basal level of mTORC1 activation but were markedly deficient in acutely re-activating mTORC1 signaling when starved and then stimulated with growth factors ${ }^{53,54}$. Likewise, the conditional $\mathrm{KO}$ of Rheb reduced but did not eliminate mTORC1 signaling in the mouse brain ${ }^{56}$. The presence of even some limited mTORC1 signaling following Rheb depletion suggested either that there might be a novel way to activate
mTORC1 that was distinct from the Rheb-dependent mechanism or that RhebL1 was able to fulfill this function. Unambiguously establishing a requirement for Rheb in activating mTORC1 was complicated by the essential role for mTORC1 signaling in promoting cell growth, which precluded the possibility of generating and maintaining animals or cells that completely lack such activity. However, the combined use of CRISPR-based mutagenesis and siRNA-mediated depletion was recently used to achieve highly efficient but transient depletion of both Rheb and RhebL1 in human cells ${ }^{57}$. This dual strategy to acutely deplete both Rheb and RhebL1 was required to fully inhibit mTORC1 signaling, and re-expression of either Rheb or RhebL1 restored mTORC1 signaling in the double depleted cells. These observations established that Rheb and RhebL1 can independently activate mTORC1 in human cells. This conclusion is further supported by in vitro assays where Rheb and RhebL1 were each able to activate $\mathrm{mTORC} 1^{58}$.

\section{Rheb farnesylation is essential for mTORC1 activation}

The coincidence detection model whereby nutrient and growth factor-dependent signaling are integrated on the surface of lysosomes by Rags and Rheb to support mTORC1 activation requires a mechanism for targeting Rheb to lysosomes. Human Rheb is a relatively simple protein that consists of just 184 amino acids that encode a GTPase domain within the first 169 amino acids followed by a short alpha helical linker known as the hypervariable region and finishing with the sequence CSVM, which conforms to the CaaX motif that is a signal for farnesylation (Figure 2) 20,50,59. Farnesylation of the Rheb C-terminal CaaX motif is part of a multi-step process of post-translational modification (Figure 2). Following addition of the 15-carbon isoprenyl-based farnesyl group by the cytoplasmic farnesyl transferase on the cysteine within the CaaX motif of Rheb, the Rheb C-terminus is further processed at the endoplasmic reticulum by Ras-converting enzyme 1 (RCE1), which removes the final three C-terminal amino acids, and isoprenylcysteine carboxyl methyltransferase (ICMT), which methylates the C-terminus ${ }^{60-62}$. These modifications, which are shared by other proteins that contain a CaaX motif, are predicted to enhance the hydrophobicity and thus membrane binding of the Rheb C-terminus ${ }^{63,64}$.

Even though farnesylation is not required for the ability of Rheb to activate mTORC1 signaling in vitro, Rheb mutants lacking the CaaX motif cannot activate mTORC1 signaling in cells $^{31,57,65}$. This is thought to reflect a critical role for farnesylation in controlling the subcellular localization of Rheb. However, farnesylation and associated C-terminal modifications are expected to support only weak and therefore transient membrane binding of Rheb $^{63,64,66}$. This weak membrane interaction that lacks specificity for a particular organelle is seemingly at odds with models that imply an enrichment of Rheb at the surface of lysosomes for the purpose of mTORC1 activation.

\section{Rheb is most prominently enriched on the endoplasmic reticulum}

Although a broadly accepted model for mTORC1 activation is centered on lysosomes ${ }^{14,15,18,67}$, early localization studies based 


\section{Rheb Maturation}

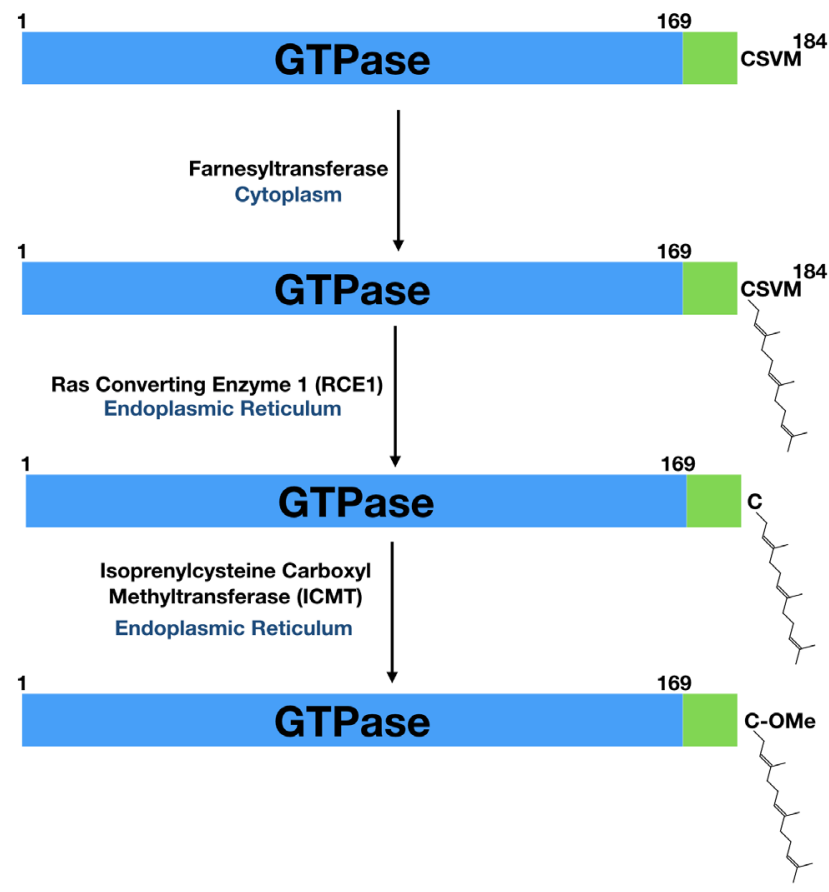

Figure 2. Rheb maturation takes place through a series of modifications to the C-terminal CaaX motif. Human Rheb is translated as a 184-amino-acid protein. The first 169 amino acids contain the GTPase domain (blue). This is followed by a short linker (green) that is sometimes referred to as the hypervariable region. The last four amino acids fit the consensus for a CaaX motif (cysteine followed by two aliphatic amino acids and with flexibility in the final position). This CaaX motif is subsequently farnesylated on the cysteine followed by trimming of the final three amino acids by the ER-localized Ras converting enzyme 1 (RCE1) and methylation of the newly exposed carboxyl group by isoprenylcysteine carboxyl methyltransferase (ICMT, also at the endoplasmic reticulum). Rheb, Ras homolog enriched in brain.

on Rheb over-expression yielded evidence of farnesylationdependent localization of Rheb to poorly defined "endomembranes" and/or to the endoplasmic reticulum and Golgi rather than a distinct enrichment on lysosomes ${ }^{60,61,65}$. It was possible that the lack of distinct lysosome localization for Rheb in these studies reflected an artifact of the over-expression of tagged Rheb proteins or a limitation of the imaging resolution. Indeed, another study which used immunofluorescence confocal microscopy with a Rheb antibody to localize the endogenous Rheb protein reported Rheb enrichment on lysosomes but still lacked the resolution to optimally resolve individual lysosomes ${ }^{37}$. However, a more recent study which used the same anti-Rheb antibody and which had improved resolution of lysosome morphology instead found that endogenously expressed Rheb predominantly localized to the endoplasmic reticulum rather than to lysosomes ${ }^{57}$. As both studies employed robust controls for establishing antibody specificity, resolution differences in these microscopy studies could potentially explain the differing conclusions regarding the presence or absence of lysosome enrichment for Rheb, as the extensive contacts between endoplasmic reticulum and lysosomes raise challenges for distinguishing between these organelles in the crowded perinuclear region of cells. As an alternative approach to defining the key determinants of Rheb localization and function, mutagenesis of putative targeting motifs within the Rheb C-terminus revealed that although farnesylation is essential for Rheb-dependent mTORC1 activation, sequences within the immediately upstream hypervariable region were not conserved between Rheb and RhebL1 and could even be replaced by an unrelated sequence derived from H-Ras ${ }^{57}$. In contrast, the last 15 amino acids of Rheb were previously reported to act as a lysosome-targeting signal that could be transplanted to other proteins in the mTORC1 pathway ${ }^{8}$. However, these seemingly disparate interpretations of the role played by the Rheb C-terminus in controlling Rheb localization and function can be resolved by a model wherein weak membrane interactions mediated by the farnesylated C-terminus allow Rheb to transiently visit lysosomes and thus increase opportunities for encountering mTORC1 that has been recruited there by interactions with the Rags. Such encounters could be achieved without requiring significant enrichment of Rheb at lysosomes. One study proposed a role for microspherule protein 1 (MCRS1) in recruiting Rheb to lysosomes ${ }^{68}$. However, this conclusion has yet to be independently corroborated. In addition, mechanisms have not been defined for the proposed regulated interactions between MCRS1 and Rheb or for MCRS1 interactions with lysosomes. Although it has been challenging to visualize Rheb enrichment on lysosomes in human cell lines, it was very recently reported that the Caenorhabditis elegans RHEB-1 protein exhibits such localization $^{69}$. This new observation raises questions about the mechanisms that target Rheb to lysosomes in this organism and how they might be regulated for the control of mTORC1 signaling in this organism, which lacks TSC.

The functional significance, if any, of the localization of Rheb to the endoplasmic reticulum remains unknown. It has been proposed that endoplasmic reticulum-localized Rheb activates mTORC1 on lysosomes via contact sites between these organelles $^{70}$. However, constitutive anchoring of Rheb on the endoplasmic reticulum via a transmembrane domain did not restore mTORC1 signaling when introduced into Rheb+RhebL1depleted cells $\mathrm{s}^{57}$. Endoplasmic reticulum localization of Rheb might not be of fundamental functional importance but may instead simply match expectations for a farnesylated protein that lacks other major determinants of subcellular targeting. This is supported by observations that farnesylation of green fluorescent protein (GFP) via the addition of a CaaX motif to its C-terminus also results in endoplasmic reticulum localization $^{71}$. Even though evidence is lacking for a model wherein endoplasmic reticulum-localized Rheb reaches across contact sites to activate mTORC1 on lysosomes, such contact sites were recently shown to influence mTORC1 signaling via oxysterol-binding protein (OSBP)-mediated cholesterol transport from the endoplasmic reticulum to lysosomes and are thus of relevance for mTORC1 signaling ${ }^{72}$. It was also proposed that Golgi-localized Rheb activates mTORC1 on lysosomes via interactions that occur across Golgi-lysosome contact sites ${ }^{73}$. However, these conclusions were based on the analysis of an 
over-expressed chimeric protein that artificially targeted Rheb to the Golgi, and it remains to be established that mTORC1 activation by the endogenous Rheb or RhebL1 proteins is dependent on sites of Golgi-lysosome contact.

The importance of fine-tuned Rheb subcellular targeting mechanisms for mTORC1 activation is highlighted by observations that mTORC1 signaling becomes insensitive to nutrient inputs when cells over-express $\mathrm{Rheb}^{51,65}$. This presumably reflects the fact that when Rheb levels are very high, mTORC1 activation no longer requires the highly regulated mechanisms that are normally required to facilitate encounters between Rheb and mTORC1 on the surface of lysosomes.

\section{Comparison of membrane targeting mechanisms between Rheb and other Ras family members}

Comparison of Rheb with other members of the Ras family reveals important differences in their membrane interaction and subcellular localization mechanisms. Like Rheb, H-Ras and K-Ras-4B are small GTPases whose protein sequences comprise the GTPase domain, a short linker, and the C-terminal CaaX motif. Nonetheless, both of these proteins are highly enriched at the plasma membrane $e^{74,75}$. This is because of conserved sequences in the hypervariable domains of H-Ras (palmitoylated cysteines) and K-Ras-4B (polybasic region) which cooperate with farnesylation to target these proteins to the plasma membrane. Meanwhile, the hypervariable region of human Rheb does not contain any known motifs to confer further specificity or affinity for interactions with specific intracellular membranes. Thus, even though evolution has selected for simple additional mechanisms for targeting other members of the human Ras superfamily to specific subcellular membranes, Rheb does not harbor additional targeting signals that lead it to be enriched on lysosomes. The fact that evolution did not select for additional membrane-targeting signals in Rheb suggests that weak farnesylation-dependent membrane interactions represent a sufficient strategy for Rheb-dependent mTORC1 activation.

\section{Support for a lysosome-localized function for Rheb}

Even though high-resolution visualization of Rheb enrichment on the surface of lysosomes in mammalian cells has been challenging to achieve and there is no defined lysosome-targeting motif within Rheb, there are still several strong arguments that support a lysosome-localized function for Rheb in the activation of mTORC1 signaling.

First, it is well established that mTORC1 recruitment to lysosomes via highly regulated interactions between Raptor and the Rag GTPases is a critical determinant of mTORC1 activation ${ }^{9,18,76,77}$. It is also clear that Rheb and RhebL1 function redundantly and are essential for mTORC1 activation in human cells ${ }^{57}$. If mTORC1 is activated at lysosomes and requires Rheb/RhebL1 for this activation, then it follows that Rheb/RhebL1 should at least visit lysosomes transiently to fulfil such a function.

Second, the TSC accumulates on the cytoplasmic surface of lysosomes in response to cell stress and nutrient deprivation ${ }^{37,78-80}$.
The presence of this GAP for Rheb on lysosomes argues that lysosomes are central to Rheb regulation. This conclusion is further supported by the observation that constitutive targeting of TSC to lysosomes suppressed mTORC1 signaling ${ }^{37}$.

Third, the Rheb gene is broadly conserved across diverse branches of the eukaryotic family tree. However, the CaaX motif that supports Rheb C-terminal farnesylation is not uniformly present ${ }^{81}$. Instead, Euglenozoa have a Rheb that lacks C-terminal farnesylation and is instead predicted to interact with membranes via an N-terminal FYVE domain. Although this FYVE domain has not yet been well-characterized, FYVE domains are best known for their ability to bind to phosphatidyl3-phosphate (PI3P) and thus recruit proteins that harbor them to endolysosomal membranes that are enriched in this lipid ${ }^{82,83}$. The presence of a FYVE domain in the Euglenozoa Rheb is thus suggestive of a function in the endolysosomal pathway. Likewise, the Rheb C-terminal CaaX motif in Cryptista is accompanied by an N-terminal PX domain, another protein module that confers weak PI3P interactions ${ }^{81}$. These putative PI3P interaction mechanisms for Rheb proteins point to the importance of weak membrane interactions and suggest a preference for endolysosomal membranes. Even for human Rheb, the requirement for C-terminal farnesylation can be overcome by providing another weak mechanism for membrane association such as that conferred by $\mathrm{N}$-terminal myristoylation ${ }^{57}$. These studies also indicate that although farnesylation of Rheb is essential for its ability to activate mTORC1, the farnesylated C-terminus is not directly part of the activation mechanism. The lack of a direct requirement for Rheb farnesylation in mTORC1 activation was also supported by in vitro assays where recombinant Rheb which lacks farnesylation still activated mTORC $1^{58}$.

\section{Rheb-independent mechanisms for mTORC1 activation in budding yeast}

Analysis of Rheb protein sequences across diverse organisms yields a diversity of putative endo-lysosomal targeting mechanisms. Although it is interesting to interpret this information in the context of what is known about human mTORC1 activation, additional functions for Rheb and alternative mechanisms for mTORC1 activation should also be considered. Phylogenetic analyses have predicted that some organisms contain genes for mTORC1 subunits (mTOR, Raptor, LST8) and yet lack $\mathrm{TSC} 1$, TSC2, and/or $\mathrm{Rheb}^{84-86}$. It remains to be determined to what extent this reflects limitations in gene annotation versus the genuine existence of alternative mechanisms for mTORC1 activation, as this pathway has not been extensively studied in many of the organisms whose sequenced genomes provided information for phylogenetic analyses. However, Saccharomyces cerevisiae, an exceedingly well-studied model organism, lacks both TSC1 and TSC2 genes $^{85-87}$. Furthermore, in spite of considerable literature focused on TORC1 signaling in budding yeast, there is currently no published demonstration that the Rheb homolog (Rhb1) is required for TORC1 signaling, although it has been implicated in the regulation of amino acid transporters $^{87}$. The lack of evidence for Rheb-dependent TORC1 activation in $S$. cerevisiae raises questions about 
how Rheb-independent TORC1 activation is achieved in this organism. Such activation still takes place on the surface of the vacuole (yeast lysosome), is regulated by nutrient availability, and is dependent on interactions with the Gtr1 and Gtr2 GTPases which are homologous to the $\mathrm{Rags}^{88}$. Interestingly, it was recently revealed that TORC1 oligomerizes on the surface of the vacuole in response to glucose deprivation and that this is required for TORC1 inactivation ${ }^{89}$. It remains to be determined whether similar oligomerization-based regulatory mechanisms for mTORC1 take place on the surface of mammalian lysosomes.

\section{PDE $\delta$ binds Rheb in the cytoplasm}

Dynamic interactions between Rheb and lysosomal membranes raise questions about factors that regulate its interactions with membranes. In contrast to the Rab subfamily of GTPases that preferentially bind to GDP dissociation inhibitor (GDI) and are thus stabilized in the cytoplasm when in the GDP-bound state, Rheb and RhebL1 do not interact with a solubilizing factor in a manner that depends on their nucleotide state ${ }^{90}$. Instead, Rheb and RhebL1 (as well as other Ras family members and many other prenylated proteins) interact in the cytoplasm with phosphodiesterase $\delta$ (PDE $\delta)^{91-93}$. PDE $\delta$ was named based on its discovery as the $\delta$ subunit of phosphodiesterase 6 , which degrades cGMP in rod and cone cells of the retina ${ }^{94}$. This interaction of PDE $\delta$ with the farnesylated PDE6 protein was later found to be generalizable to other farnesylated proteins such as Rheb, other Ras family members, and many other proteins that undergo C-terminal prenylation (farnesylation or geranylgeranylation $)^{95-97}$. An explanation for the ability of PDE $\delta$ to bind to so many structurally distinct proteins whose only common feature is C-terminal prenylation came from a crystal structure of Rheb in complex with PDE $\delta$, which revealed that the interaction is mediated by the insertion of the farnesyl group deep within a hydrophobic cavity on PDE $\delta$ without the need for any major contacts between the rest of the Rheb protein and PDE $\delta$ (Figure 3). Owing to the minimal contact between the protein part of Rheb and PDE $\delta$, this mode of interaction is insensitive to the Rheb nucleotide state ${ }^{91}$. A role for PDE $\delta$ in the regulation of Rheb function is consistent with the inhibition of mTORC1 signaling following treatment of cells with deltarasin, a drug that competes with Rheb for binding to the hydrophobic pocket of $\operatorname{PDE} \delta^{57,98}$. However, because of the many prenylated protein partners of PDE $\delta$ whose function might also be perturbed by deltarasin, multiple factors beyond just the disruption of Rheb-PDE $\delta$ interactions could contribute to the effect of deltarasin on mTORC1 signaling.

The displacement of prenylated proteins such as Rheb from PDE $\delta$ is stimulated by Arl2, a small GTPase ${ }^{91,99-101}$. Although a comparable ability of Arl3 to promote dissociation of Rheb from PDE $\delta$ was previously reported ${ }^{91}$, it now appears that Arl3 function is most physiologically important at cilia, where it promotes the release of myristoylated cargos from another set of solubilizing factors known as UNC119a and UNC119b ${ }^{102}$. Meanwhile, the relevance of Arl2 for prenylated protein displacement from PDE $\delta$ is supported by the observation that Arl2 depletion from cells is sufficient to suppress the release of $\mathrm{K}$-Ras from $\mathrm{PDE}^{22}$. This Arl2-dependent re-targeting mechanism
A

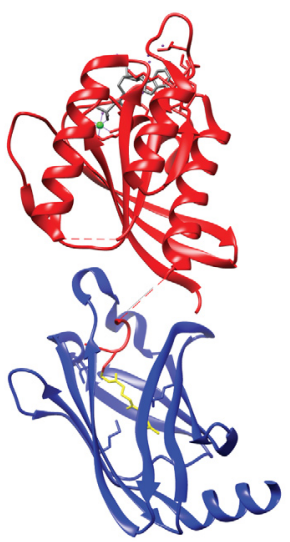

B

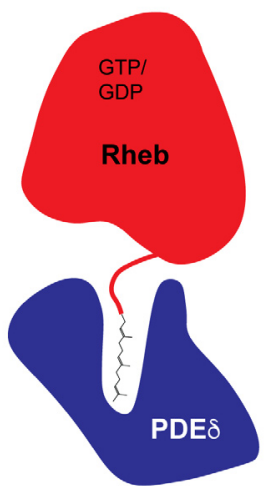

Figure 3. Rheb C-terminal farnesylation allows for interactions with PDE $\delta$. (A) A structure (3T5G) of the complex formed between Rheb (red) and PDE $\delta$ (blue) reveals that the interaction is largely independent of contacts between the Rheb and PDE $\delta$ proteins and is instead based on the insertion of the Rheb farnesyl group (yellow) deep into a hydrophobic cavity within PDE $\delta^{91}$. Additional features include GDP bound to Rheb in gray, $\mathrm{Mg}^{+}$in green, and water molecules in purple. (B) Schematic diagram of the Rheb-PDE $\delta$ heterodimer which highlights the insertion of the farnesyl group from Rheb deep into the hydrophobic cavity at the core of PDE $\delta$. PDE $\delta, \delta$ subunit of phosphodiesterase 6; Rheb, Ras homolog enriched in brain.

is thought to prevent entropic randomization of the distribution of prenylated client proteins and was recently suggested to play a role in the regulation of Rheb-dependent mTORC1 activation $^{103}$. At the moment, relatively few studies have investigated the interaction between PDE $\delta$ and Rheb, the impact of this interaction on Rheb subcellular localization, and the overall consequences of PDE $\delta$-dependent mechanisms for mTORC1 signaling. Further research is required to define how regulation of the interactions between Rheb and PDE $\delta$ is integrated with the overall control of mTORC1 signaling by the rest of the cellular machinery dedicated to sensing and responding to changes in nutrient and growth factor availability. If the importance of PDE $\delta$ for mTORC1 signaling is solidified by additional studies, then it will become critical to answer questions about the identity, regulation, and subcellular localization of the Arl2 GEF(s).

\section{Summary}

Although Rheb is not highly enriched at lysosomes, multiple lines of evidence coming from studies of the subcellular localization of Rheb targets and regulatory proteins, rescue assays in Rheb/RhebL1-depleted cells, and phylogenetic analyses support a model wherein Rheb transiently visits the surface of lysosomes in order to activate mTORC1. In human Rheb, the weak membrane interactions that are conferred by farnesylation fulfil this role. In contrast to expectations for other small GTPases that exhibit more robust enrichment on target membranes and well-defined mechanisms for supporting such localization, the dynamic membrane-targeting ability conferred by Rheb C-terminal farnesylation coupled with weak 
interactions between mTORC1 and Rheb may be sufficient to facilitate the initial encounter with lysosome-localized mTORC1 via a reduction of dimensionality but still allow activated mTORC1 to leave lysosomes in order to phosphorylate downstream targets elsewhere in the cell. Although much has been discovered with respect to mechanisms of Rhebdependent mTORC1 activation, it remains unclear whether Rheb must remain bound to mTORC1 in order to maintain the kinase activity of TOR and whether additional regulatory mechanisms act through Rheb to terminate this signaling.

\section{Acknowledgements}

We appreciate generous assistance from Gabriel Talaia (Department of Cell Biology, Yale University, USA) in the analysis and presentation of Rheb-PDE $\delta$ structures.
1. F Yang $\mathrm{H}$, Jiang $\mathrm{X}$, Li B, et al.: Mechanisms of mTORC1 activation by RHEB and inhibition by PRAS40. Nature. 2017; 552(7685): 368-373. PubMed Abstract | Publisher Full Text | Free Full Text | Faculty Opinions Recommendation

2. Long $X$, Ortiz-Vega S, Lin $Y$, et al:: Rheb binding to mammalian target of rapamycin (mTOR) is regulated by amino acid sufficiency. J Biol Chem. 2005; 280(25): 23433-6.

PubMed Abstract | Publisher Full Text

3. Kim DH, Sarbassov DD, Ali SM, et al:: mTOR Interacts with Raptor to Form a Nutrient-Sensitive Complex that Signals to the Cell Growth Machinery. Cell. 2002; 110(2): 163-75

PubMed Abstract | Publisher Full Text

4. Hara K, Maruki Y, Long X, et al:: Raptor, a Binding Partner of Target of Rapamycin (TOR), Mediates TOR Action. Cell. 2002; 110(2): 177-89. PubMed Abstract | Publisher Full Text

5. Loewith R, Jacinto E, Wullschleger S, et al:: Two TOR Complexes, Only One of which Is Rapamycin Sensitive, Have Distinct Roles in Cell Growth Control. Mol Cell. 2002; 10(3): 457-68

PubMed Abstract | Publisher Full Text

6. Nojima H, Tokunaga C, Eguchi S, et al:: The mammalian target of rapamycin (mTOR) partner, raptor, binds the mTOR substrates p70 S6 kinase and 4E-BP1 through their TOR signaling (TOS) motif. J Biol Chem. 2003; 278(18): 15461-4. PubMed Abstract | Publisher Full Text

7. Schalm SS, Fingar DC, Sabatini DM, et al:: TOS Motif-Mediated Raptor Binding Regulates 4E-BP1 Multisite Phosphorylation and Function. Curr Biol. 2003; 13(10): 797-806 PubMed Abstract | Publisher Full Text

8. F Sancak Y, Bar-Peled L, Zoncu R, et al:: Ragulator-Rag complex targets mTORC1 to the lysosomal surface and is necessary for its activation by amino acids. Cell. 2010; 141(2): 290-303.

PubMed Abstract | Publisher Full Text | Free Full Text

Faculty Opinions Recommendation

9. F Sancak Y, Peterson TR, Shaul YD, et al:: The Rag GTPases Bind Raptor and Mediate Amino Acid Signaling to mTORC1. Science. 2008; 320(5882): 1496-501. PubMed Abstract | Publisher Full Text | Free Full Text | Faculty Opinions Recommendation

10. F Sarbassov DD, Ali SM, Kim DH, et al:: Rictor, a novel binding partner of mTOR, defines a rapamycin-insensitive and raptor-independent pathway that regulates the cytoskeleton. Curr Biol. 2004; 14(14): 1296-302. PubMed Abstract | Publisher Full Text | Faculty Opinions Recommendation

11. Yang Q, Inoki K, Kim E, et al:: TSC1/TSC2 and Rheb have different effects on TORC1 and TORC2 activity. Proc Natl Acad Sci U S A. 2006; 103(18): 6811-6. PubMed Abstract | Publisher Full Text | Free Full Text

12. González A, Hall MN: Nutrient sensing and TOR signaling in yeast and mammals. EMBO J. 2017; 36(4): 397-408. PubMed Abstract | Publisher Full Text | Free Full Text

13. Ben-Sahra I, Manning BD: mTORC1 signaling and the metabolic control of cell growth. Curr Opin Cell Biol. 2017; 45: 72-82. PubMed Abstract | Publisher Full Text | Free Full Text

14. $\mathrm{F}$ Betz $\mathrm{C}$, Hall MN: Where is $\mathbf{m T O R}$ and what is it doing there? J Cell Biol. 2013; 203(4): 563-74.

PubMed Abstract | Publisher Full Text | Free Full Text | Faculty Opinions Recommendation

15. Ferguson SM: Beyond indigestion: Emerging roles for lysosome-based signaling in human disease. Curr Opin Cell Biol. 2015; 35: 59-68. PubMed Abstract | Publisher Full Text | Free Full Text

16. Lim $\mathrm{CY}$, Zoncu R: The lysosome as a command-and-control center for cellular metabolism. J Cell Biol. 2016; 214(6): 653-64.

PubMed Abstract | Publisher Full Text | Free Full Text

17. Jewell JL, Russell RC, Guan KL: Amino acid signalling upstream of mTOR. Nat Rev Mol Cell Biol. 2013; 14(3): 133-9.

PubMed Abstract | Publisher Full Text | Free Full Text

18. F Liu GY, Sabatini DM: mTOR at the nexus of nutrition, growth, ageing and disease. Nat Rev Mol Cell Biol. 2020; 21(4): 183-203. PublMed Abstract | Publisher Full Text | Free Full Text | Faculty Opinions Recommendation

19. Kim E, Goraksha-Hicks P, Li L, et al.: Regulation of TORC1 by Rag GTPases in nutrient response. Nat Cell Biol. 2008; 10(8): 935-45. PubMed Abstract | Publisher Full Text | Free Full Text

20. Yamagata K, Sanders LK, Kaufmann WE, et al:: rheb, a growth factor- and synaptic activity-regulated gene, encodes a novel Ras-related protein. $J$ Biol Chem. 1994; 269(23): 16333-9. PubMed Abstract

21. Nada S, Hondo A, Kasai A, et al.: The novel lipid raft adaptor p18 controls endosome dynamics by anchoring the MEK-ERK pathway to late endosomes. EMBO J. 2009; 28(5): 477-89.

PubMed Abstract | Publisher Full Text | Free Full Text

22. Sanders SS, de Simone FI, Thomas GM: mTORC1 Signaling Is PalmitoylationDependent in Hippocampal Neurons and Non-neuronal Cells and Involves Dynamic Palmitoylation of LAMTOR1 and mTOR. Front Cell Neurosci. 2019; 13 115.

PubMed Abstract | Publisher Full Text | Free Full Text

23. F Yip CK, Murata K, Walz T, et al.: Structure of the Human mTOR Complex I and Its Implications for Rapamycin Inhibition. Mol Cell. 2010; 38(5): 768-74. PubMed Abstract | Publisher Full Text | Free Full Text | Faculty Opinions Recommendation

24. F Stocker H, Radimerski T, Schindelholz B, et al:: Rheb is an essential regulator of S6K in controlling cell growth in Drosophila. Nat Cell Biol. 2003; 5(6): 559-65.

PubMed Abstract | Publisher Full Text | Faculty Opinions Recommendation

25. $\mathrm{F}$ Zhang $\mathrm{Y}, \mathrm{Gao} X$, Saucedo LJ, et al.: Rheb is a direct target of the tuberous sclerosis tumour suppressor proteins. Nat Cell Biol. 2003; 5(6): 578-81. PubMed Abstract | Publisher Full Text | Faculty Opinions Recommendation

26. Patel PH, Thapar N, Guo L, et al:: Drosophila Rheb GTPase is required for cell cycle progression and cell growth. J Cell Sci. 2003; 116(Pt 17): 3601-10. PubMed Abstract | Publisher Full Text

27. F Saucedo LJ, Gao X, Chiarelli DA, et al.: Rheb promotes cell growth as a component of the insulin/TOR signalling network. Nat Cell Biol. 2003; 5(6): $566-71$.

PubMed Abstract | Publisher Full Text | Faculty Opinions Recommendation

28. Castro AF, Rebhun JF, Clark GJ, et al:: Rheb binds tuberous sclerosis complex 2 (TSC2) and promotes 56 kinase activation in a rapamycin- and farnesylationdependent manner. J Biol Chem. 2003; 278(35): 32493-6. PubMed Abstract | Publisher Full Text

29. Garami A, Zwartkruis FJT, Nobukuni T, et al.: Insulin Activation of Rheb, a Mediator of mTOR/S6K/4E-BP Signaling, Is Inhibited by TSC1 and 2. Mol Cell. 2003; 11(6): 1457-66. PubMed Abstract | Publisher Full Text

30. Inoki K, Li Y, Xu T, et al.: Rheb GTPase is a direct target of TSC2 GAP activity and regulates mTOR signaling. Genes Dev. 2003; 17(15): 1829-34. PubMed Abstract | Publisher Full Text | Free Full Text

31. Tee AR, Manning BD, Roux PP, et al:: Tuberous Sclerosis Complex Gene Products, Tuberin and Hamartin, Control mTOR Signaling by Acting as a 
GTPase-Activating Protein Complex toward Rheb. Curr Biol. 2003; 13(15): 1259-68.

PubMed Abstract | Publisher Full Text

32. Huang J, Manning BD: The TSC1-TSC2 complex: A molecular switchboard controlling cell growth. Biochem J. 2008; 412(2): 179-90.

PubMed Abstract | Publisher Full Text | Free Full Text

33. F Potter CJ, Pedraza LG, Xu T: Akt regulates growth by directly phosphorylating Tsc2. Nat Cell Biol. 2002; 4(9): 658-65. PubMed Abstract | Publisher Full Text | Faculty Opinions Recommendation

34. Inoki K, Li Y, Zhu T, et al.: TSC2 is phosphorylated and inhibited by Akt and suppresses mTOR signalling. Nat Cell Biol. 2002; 4(9): 648-57. PubMed Abstract | Publisher Full Text

35. Manning BD, Tee AR, Logsdon MN, et al:: Identification of the Tuberous Sclerosis Complex-2 Tumor Suppressor Gene Product Tuberin as a Target of the Phosphoinositide 3-Kinase/Akt Pathway. Mol Cell. 2002; 10(1): 151-62. PubMed Abstract | Publisher Full Text

36. Li Y, Inoki K, Yeung R, et al.: Regulation of TSC2 by 14-3-3 binding. J Biol Chem 2002; 277(47): 44593-6. PubMed Abstract | Publisher Full Text

37. F Menon S, Dibble CC, Talbott G, et al.: Spatial control of the TSC complex integrates insulin and nutrient regulation of $\mathrm{mTORC} 1$ at the lysosome. Cell. 2014; 156(4): 771-85

PubMed Abstract | Publisher Full Text | Free Full Text |

Faculty Opinions Recommendation

38. Nellist M, Goedbloed MA, de Winter C, et al.: Identification and characterization of the interaction between tuberin and 14-3-3zeta. J Biol Chem. 2002; 277(42): 39417-24.

PubMed Abstract | Publisher Full Text

39. Cai SL, Tee AR, Short JD, et al:: Activity of TSC2 is inhibited by AKT-mediated phosphorylation and membrane partitioning. J Cell Biol. 2006; 173(2): 279-89. PubMed Abstract | Publisher Full Text | Free Full Text

40. Liu MY, Cai S, Espejo A, et al:: 14-3-3 interacts with the tumor suppressor tuberin at Akt phosphorylation site(s). Cancer Res. 2002; 62(22): 6475-80. PubMed Abstract

41. Henske EP, Jóźwiak S, Kingswood JC, et al.: Tuberous sclerosis complex. Nat Rev Dis Primers. 2016; 2: 16035 PubMed Abstract | Publisher Full Tex

42. F Winden KD, Ebrahimi-Fakhari D, Sahin M: Abnormal mTOR Activation in Autism. Annu Rev Neurosci. 2018; 41: 1-23. PubMed Abstract | Publisher Full Text | Faculty Opinions Recommendation

43. Mahoney SJ, Narayan S, Molz L, et al: A small molecule inhibitor of Rheb selectively targets mTORC1 signaling. Nat Commun. 2018; 9(1): 548 . PubMed Abstract | Publisher Full Text | Free Full Text

44. F Gasper R, Wittinghofer F: The Ras Switch in Structural and Historical Perspective. Biol Chem. 2019; 401(1): 143-63. PubMed Abstract | Publisher Full Text | Faculty Opinions Recommendation

45. Rehmann $\mathrm{H}$, Brüning $\mathrm{M}$, Berghaus $\mathrm{C}$, et al.: Biochemical Characterisation of TCTP Questions Its Function as a Guanine Nucleotide Exchange Factor for Rheb. FEBS Lett. 2008; 582(20): 3005-10.

PubMed Abstract | Publisher Full Text

46. Wang X, Fonseca BD, Tang $\mathrm{H}$, et al:: Re-evaluating the Roles of Proposed Modulators of Mammalian Target of Rapamycin Complex 1 (mTORC1) Signaling. J Biol Chem 2008; 283(45): 30482-92. PubMed Abstract | Publisher Full Text | Free Full Text

47. Maeurer C, Holland S, Pierre S, et al:: Sphingosine-1-phosphate Induced mTORactivation Is Mediated by the E3-ubiquitin Ligase PAM. Cell Signal. 2009; 21(2): 293-300.

PubMed Abstract | Publisher Full Text

48. Sancak $Y$, Thoreen CC, Peterson TR: PRAS40 Is an Insulin-Regulated Inhibitor of the mTORC1 Protein Kinase. Mol Cell. 2007; 25(6): 903-15. PubMed Abstract | Publisher Full Text

49. Warne PH, Viciana PR, Downward J: Direct Interaction of Ras and the AminoTerminal Region of Raf-1 in vitro. Nature. 1993; 364(6435): 352-5. PubMed Abstract | Publisher Full Text

50. Ahearn IM, Haigis K, Bar-Sagi D, et al.: Regulating the Regulator: PostTranslational Modification of RAS. Nat Rev Mol Cell Biol. 2011; 13(1): 39-51. PubMed Abstract | Publisher Full Text | Free Full Text

51. Tee AR, Blenis J, Proud CG: Analysis of mTOR Signaling by the Small G-proteins, Rheb and RhebL1. FEBS Lett. 2005; 579(21): 4763-8. PubMed Abstract | Publisher Full Text

52. Tabancay AP, Gau CL, Machado IMP et al: Identification of Dominant Negative Mutants of Rheb GTPase and Their Use to Implicate the Involvement of Human Rheb in the Activation of p70S6K. J Biol Chem. 2003; 278(41): 39921-30. PubMed Abstract | Publisher Full Text

53. Goorden SMI, Hoogeveen-Westerveld M, Cheng C, et al.: Rheb Is Essential for Murine Development. Mol Cell Biol. 2011; 31(8): 1672-8. PubMed Abstract | Publisher Full Text | Free Full Text

54. Groenewoud MJ, Goorden SMI, Kassies J, et al:: Mammalian target of rapamycin complex I (mTORC1) activity in ras homologue enriched in brain (Rheb)deficient mouse embryonic fibroblasts. PLOS One. 2013; 8(11): e81649. PubMed Abstract | Publisher Full Text | Free Full Text
55. Zou J, Zhou L, Du XX, et al.: Rheb1 is required for mTORC1 and myelination in postnatal brain development. Dev Cell. 2011; 20(1): 97-108.

PubMed Abstract | Publisher Full Text | Free Full Text

56. Goorden SMI, Abs E, Bruinsma CF, et al:: Intact neuronal function in Rheb1 mutant mice: Implications for TORC1-based treatments. Hum Mol Genet. 2015 24(12): 3390-8

PubMed Abstract | Publisher Full Text

57. Angarola B, Ferguson SM: Weak membrane interactions allow Rheb to activate mTORC1 signaling without major lysosome enrichment. Mol Biol Cell. 2019; 30(22): 2750-2760.

PubMed Abstract | Publisher Full Text | Free Full Text

58. F Sato T, Nakashima A, Guo L, et al:: Specific activation of mTORC1 by Rheb G-protein in vitro involves enhanced recruitment of its substrate protein. J Biol Chem. 2009; 284(19): 12783-91.

PubMed Abstract | Publisher Full Text | Free Full Text |

Faculty Opinions Recommendation

59. Clark GJ, Kinch MS, Rogers-Graham K, et al.: The Ras-related Protein Rheb Is Farnesylated and Antagonizes Ras Signaling and Transformation. J Biol Chem. 1997; 272(16): 10608-15.

PubMed Abstract | Publisher Full Text

60. Hanker AB, Mitin N, Wilder RS, et al.: Differential requirement of CAAX-mediated posttranslational processing for Rheb localization and signaling. Oncogene. 2010; 29(3): 380-91.

PubMed Abstract | Publisher Full Text | Free Full Text

61. Takahashi K, Nakagawa M, Young SG, et al:: Differential Membrane Localization of ERas and Rheb, Two Ras-related Proteins Involved in the Phosphatidylinositol 3-Kinase/mTOR Pathway. J Biol Chem. 2005; 280(38): 32768-74.

PubMed Abstract | Publisher Full Text

62. F Diver MM, Pedi L, Koide A, et al.: Atomic structure of the eukaryotic ntramembrane RAS methyltransferase ICMT. Nature. 2018; 553(7689): 526-529. PubMed Abstract | Publisher Full Text | Free Full Text | Faculty Opinions Recommendation

63. Silvius JR, Bhagatji P, Leventis R, et al.: K-ras4B and prenylated proteins lacking "second signals" associate dynamically with cellular membranes. Mol Biol Cell. 2006; 17(1): 192-202.

PubMed Abstract | Publisher Full Text | Free Full Text

64. Silvius JR, l'Heureux F: Fluorimetric evaluation of the affinities of isoprenylated peptides for lipid bilayers. Biochemistry. 1994; 33(10): 3014-22. PubMed Abstract | Publisher Full Text

65. Buerger C, DeVries B, Stambolic V: Localization of Rheb to the endomembrane is critical for its signaling function. Biochem Biophys Res Commun. 2006; 344(3): 869-80.

PubMed Abstract | Publisher Full Text

66. Brunsveld L, Waldmann $\mathrm{H}$, Huster $\mathrm{D}$ : Membrane binding of lipidated Ras peptides and proteins - The structural point of view. Biochim Biophys Acta. 2009; 1788(1): 273-88.

PubMed Abstract | Publisher Full Text

67. F Lawrence RE, Zoncu R: The lysosome as a cellular centre for signalling, metabolism and quality control. Nat Cell Biol. 2019; 21(2): 133-142. PubMed Abstract | Publisher Full Text | Faculty Opinions Recommendation

68. Fawal MA, Brandt M, Djouder N: MCRS1 binds and couples Rheb to amino acid-dependent mTORC1 activation. Dev Cell. 2015; 33(1): 67-81. PubMled Abstract | Publisher Full Text

69. Duong $\mathrm{T}$, Rasmussen NR, Ballato $\mathrm{E}$, et al:: The Rheb-TORC1 signaling axis functions as a developmental checkpoint. Development. 2020; 147(5): dev181727.

PubMed Abstract | Publisher Full Text | Free Full Text

70. F Walton ZE, Patel CH, Brooks RC, et al.: Acid Suspends the Circadian Clock in Hypoxia through Inhibition of mTOR. Cell. 2018; 174(1): 72-87.e32. PubMed Abstract | Publisher Full Text | Free Full Text | Faculty Opinions Recommendation

71. Choy E, Chiu VK, Silletti J, et al:: Endomembrane trafficking of ras: the CAAX motif targets proteins to the ER and Golgi. Cell. 1999; 98(1): 69-80. PubMed Abstract | Publisher Full Text

72. F Lim CY, Davis OB, Shin HR, et al:: ER-lysosome contacts enable cholestero sensing by mTORC1 and drive aberrant growth signalling in Niemann-Pick type C. Nat Cell Biol. 2019; 21(10): 1206-1218. PubMed Abstract | Publisher Full Text | Free Full Text | Faculty Opinions Recommendation

73. $\mathrm{F}$ Hao $\mathrm{F}$, Kondo $\mathrm{K}$, Itoh $\mathrm{T}$, et al:: Rheb localized on the Golgi membrane activates lysosome-localized mTORC1 at the Golgi-lysosome contact site. J Cell Sci. 2018; 131(3): jcs208017.

PubMed Abstract | Publisher Full Text | Faculty Opinions Recommendation

74. F Zhou Y, Hancock JF: Deciphering lipid codes: K-Ras as a paradigm. Traffic. 2018; 19(3): 157-65.

PubMed Abstract | Publisher Full Text | Free Full Text | Faculty Opinions Recommendation

75. Hancock JF, Paterson $\mathrm{H}$, Marshall $\mathrm{CJ}$ : A polybasic domain or palmitoylation is required in addition to the CAAX motif to localize p21ras to the plasma membrane. Cell. 1990; 63(1): 133-9.

PubMed Abstract | Publisher Full Text 
76. F Anandapadamanaban M, Masson GR, Perisic O, et al:: Architecture of human Rag GTPase heterodimers and their complex with mTORC1. Science. 2019; 366(6462): 203-10

PubMed Abstract | Publisher Full Text | Free Full Text

Faculty Opinions Recommendation

77. F Rogala KB, Gu X, Kedir JF, et al.: Structural basis for the docking of mTORC1 on the lysosomal surface. Science. 2019; 366(6464): 468-75. PubMed Abstract | Publisher Full Text | Free Full Text | Faculty Opinions Recommendation

78. F Demetriades C, Doumpas N, Teleman AA: Regulation of TORC1 in response to amino acid starvation via lysosomal recruitment of TSC2. Cell. 2014; 156(4): 786-99.

PubMed Abstract | Publisher Full Text | Free Full Text

Faculty Opinions Recommendation

79. Demetriades C, Plescher M, Teleman AA: Lysosomal recruitment of TSC2 is a universal response to cellular stress. Nat Commun. 2016; 7: 10662. PubMed Abstract | Publisher Full Text | Free Full Text

80. F Carroll B, Maetzel D, Maddocks OD, et al: Control of TSC2-Rheb signaling axis by arginine regulates mTORC1 activity. eLife. 2016; 5: e11058. PubMed Abstract | Publisher Full Text | Free Full Text | Faculty Opinions Recommendation

81. F Záhonová $\mathrm{K}$, Petrželková R, Valach $\mathrm{M}$, et al.: Extensive molecular tinkering in the evolution of the membrane attachment mode of the Rheb GTPase. Sci Rep. 2018; 8(1): 5239

PubMed Abstract | Publisher Full Text | Free Full Text Faculty Opinions Recommendation

82. Di Paolo G, de Camilli P: Phosphoinositides in cell regulation and membrane dynamics. Nature. 2006; 443(7112): 651-7. PubMed Abstract | Publisher Full Text

83. Burd CG, Emr SD: Phosphatidylinositol(3)-Phosphate Signaling Mediated by Specific Binding to RING FYVE Domains. Mol Cell. 1998; 2(1): 157-62. PubMed Abstract | Publisher Full Text

84. van Dam TJP, Zwartkruis FJT, Bos JL, et al:: Evolution of the TOR pathway. J Mol Evol. 2011; 73(3-4): 209-20.

PubMed Abstract | Publisher Full Text | Free Full Text

85. Shertz CA, Bastidas RJ, Li W, et al:: Conservation, duplication, and loss of the Tor signaling pathway in the fungal kingdom. BMC Genomics. 2010; 11: 510 PubMed Abstract | Publisher Full Text | Free Full Text

86. Tatebe H, Shiozaki K: Evolutionary Conservation of the Components in the TOR Signaling Pathways. Biomolecules. 2017; 7(4): 77. PubMed Abstract | Publisher Full Text | Free Full Text

87. Urano J, Tabancay AP, Yang W, et al.: The Saccharomyces cerevisiae Rheb G-protein is involved in regulating canavanine resistance and arginine uptake. J Biol Chem. 2000; 275(15): 11198-206.

PubMed Abstract | Publisher Full Text

88. Nicastro R, Sardu A, Panchaud N, et al:: The Architecture of the Rag GTPase Signaling Network. Biomolecules. 2017; 7(3): 48. PubMed Abstract | Publisher Full Text | Free Full Text

89. F Prouteau M, Desfosses A, Sieben C, et al:: TORC1 organized in inhibited domains (TOROIDs) regulate TORC1 activity. Nature. 2017; 550(7675): 265-269. PubMed Abstract | Publisher Full Text | Free Full Text | Faculty Opinions Recommendation
90. Stenmark H: Rab GTPases as coordinators of vesicle traffic. Nat Rev Mol Cell Biol. 2009; 10(8): 513-25

PubMed Abstract | Publisher Full Text

91. F Ismail SA, Chen YX, Rusinova A, et al:: Arl2-GTP and Arl3-GTP regulate a GDI-like transport system for farnesylated cargo. Nat Chem Biol. 2011; 7(12): 942-9.

PubMed Abstract | Publisher Full Text | Faculty Opinions Recommendation

92. F Schmick M, Vartak N, Papke B, et al.: KRas Localizes to the Plasma Membrane by Spatial Cycles of Solubilization, Trapping and Vesicular Transport. Cell. 2014; 157(2): 459-471.

PubMed Abstract | Publisher Full Text | Faculty Opinions Recommendation

93. Schmick M, Kraemer A, Bastiaens PIH: Ras moves to stay in place. Trends Cell Biol. 2015; 25: 190-7.

PubMed Abstract | Publisher Full Text

94. Florio SK, Prusti RK, Beavo JA: Solubilization of Membrane-bound Rod Phosphodiesterase by the Rod Phosphodiesterase Recombinant $\delta$ Subunit. J Biol Chem. 1996; 271(39): 24036-47. PubMed Abstract | Publisher Full Text

95. Zhang $\mathrm{H}$, Liu Xh, Zhang K, et al:: Photoreceptor cGMP phosphodiesterase delta subunit (PDEdelta) functions as a prenyl-binding protein. J Biol Chem. 2004; 279(1): 407-13.

PubMed Abstract | Publisher Full Tex

96. Nancy V, Callebaut I, El Marjou A, et al.: The delta subunit of retinal rod cGMP phosphodiesterase regulates the membrane association of Ras and Rap GTPases. J Biol Chem. 2002; 277(17): 15076-84. PubMed Abstract | Publisher Full Text

97. F Chandra A, Grecco HE, Pisupati V, et al:: The GDI-like solubilizing factor PDE $\delta$ sustains the spatial organization and signalling of Ras family proteins. Nat Cell Biol. 2011; 14(2): 148-58.

PubMed Abstract | Publisher Full Text | Faculty Opinions Recommendation

98. F Zimmermann G, Papke B, Ismail S, et al:: Small molecule inhibition of the KRAS-PDE $\delta$ interaction impairs oncogenic KRAS signalling. Nature. 2013; 497(7451): 638-42.

PubMed Abstract | Publisher Full Text | Faculty Opinions Recommendation

99. F Hanzal-Bayer M, Renault L, Roversi P, et al.: The complex of Arl2-GTP and PDEdelta: From structure to function. EMBO J. 2002; 21(9): 2095-106. PubMed Abstract | Publisher Full Text | Free Full Text | Faculty Opinions Recommendation

100. Hanzal-Bayer M, Linari M, Wittinghofer A: Properties of the Interaction of Arf-like Protein 2 with PDEס. J Mol Biol. 2005; 350(5): 1074-82. PubMed Abstract | Publisher Full Text

101. Fansa EK, Wittinghofer A: Sorting of lipidated cargo by the Arl2/Arl3 system. Small GTPases. 2016; 7(4): 222-230. PubMed Abstract | Publisher Full Text | Free Full Text

102. Ismail SA, Chen $Y X$, Miertzschke M, et al:: Structural basis for Arl3-specific release of myristoylated ciliary cargo from UNC119. EMBO J. 2012; 31(20): 4085-94.

PubMed Abstract | Publisher Full Text | Free Full Text

103. Kovacevic $\mathrm{M}$, Klein $\mathrm{CH}$, Roßmannek $\mathrm{L}$, et al:: A spatially regulated GTPase cycle of Rheb controls growth factor signaling to mTORC1. BioRXiv. 2018.

Publisher Full Text 


\section{Open Peer Review}

\section{Current Peer Review Status:}

\section{Editorial Note on the Review Process}

Faculty Reviews are review articles written by the prestigious Members of Faculty Opinions. The articles are commissioned and peer reviewed before publication to ensure that the final, published version is comprehensive and accessible. The reviewers who approved the final version are listed with their names and affiliations.

\section{The reviewers who approved this article are:}

\section{Version 1}

\section{Roberto Zoncu}

Department of Molecular and Cell Biology, University of California at Berkeley, Berkeley, CA, USA Competing Interests: No competing interests were disclosed.

\section{Robbie Loewith}

Department of Molecular Biology and Swiss National Centre for Competence in Research (NCCR) in Chemical Biology, University of Geneva, Sciences II, Geneva, Switzerland

Competing Interests: No competing interests were disclosed.

\section{David M Sabatini}

Whitehead Institute for Biomedical Research, Howard Hughes Medical Institute, Massachusetts Institute of Technology, The David H. Koch Institute for Integrative Cancer Research, Cambridge, MA, USA

\section{Justin Roberts}

Whitehead Institute for Biomedical Research, Howard Hughes Medical Institute, Massachusetts Institute of Technology, The David H. Koch Institute for Integrative Cancer Research, Cambridge, MA, USA

Competing Interests: No competing interests were disclosed.

\section{Rolf Heumann}

Department of Biochemistry II-Molecular Neurobiochemistry, Faculty of Chemistry and Biochemistry, Ruhr-Universität Bochum, Bochum, Germany

Competing Interests: No competing interests were disclosed. 
The benefits of publishing with F1000Research:

- Your article is published within days, with no editorial bias

- You can publish traditional articles, null/negative results, case reports, data notes and more

- The peer review process is transparent and collaborative

- Your article is indexed in PubMed after passing peer review

- Dedicated customer support at every stage

For pre-submission enquiries, contact research@f1000.com 